\title{
Succession of microfungal communities on decaying leaves of Castanopsis fissa
}

\author{
Alvin M.C. Tang, Rajesh Jeewon, and Kevin D. Hyde
}

\begin{abstract}
A total of 38 fungal taxa were identified on senescent untreated and autoclaved Castanopsis fissa leaves during a 4-month study period. Seventy-six percent of the fungal genera found in this survey have not previously been recorded from Castanopsis. Frequency and time of occurrence of fungal taxa occurring on untreated senescent leaves were clustered into four groups when analyzed by cluster analysis, suggesting the replacement of microfungi in stages of succession on naturally senescent leaves. Autoclaved leaves revealed significantly different fungal communities, with only $26 \%$ of overlap with the natural ones and no clear patterns of replacement of fungal communities. Factors regulating the rates of decomposition are also discussed.
\end{abstract}

Key words: Castanopsis, decomposition fungal ecology, fungal succession, microfungi.

Résumé : Lors d'une étude d'une durée de 4 mois, un total de 38 taxa fongiques ont été identifiés sur des feuilles de Castanopsis fissa en sénescence, non traitées et autoclavées. Soixante-seize pour cent des genres fongiques trouvés lors de cette étude n'avaient pas été précédemment répertoriés pour Castanopsis. La fréquence et la temps d'apparition des taxa fongiques se trouvant sur les feuilles sénescentes non traitées ont été rassemblés en quatre groupes suivant une analyse typologique, suggérant un remplacement des micro-champignons par stades successifs, sur les feuilles naturellement sénescentes. Les feuilles autoclavées ont révélé un patron différent de communautés fongiques, présentant seulement $26 \%$ de chevauchement avec les communautés naturelles. sans patron clair de remplacement des communautés fongiques. Nous discutons aussi des facteurs qui régulent les taux de décomposition.

Mots clés : Castanopsis, écologie de la décomposition fongique, succession fongique, champignons microscopiques.

[Traduit par la Rédaction]

\section{Introduction}

Decomposition of plant litter is a key process in recycling of nutrients and formation of humus in forest ecosystems (Swift et al. 1979). Through this process, nutrients that are immobilized in the detritus are mineralized and released into the soil in a form suitable for plant uptake (Cotrufo et al. 2000). The role of litter fungi is crucial in the decomposition process, since they are able to degrade the lignocellulose matrix in litter, while other organisms cannot (AbdelRaheem and Shearer 2002; Risna and Suhirman 2002; Urairuj et al. 2003). Thus, fungal and microbial biomass can control significant fractions of nutrient compositions in forests (Marumoto et al. 1982; Yang and Insam 1991). Decomposition processes are regulated by the combined effects of resource composition (chemical and physical composition of the litter), physicochemical environment (e.g., moisture, pH, solar radiation, and temperature), and the decomposer organisms (Swift et al. 1979; Williams and Gray 1974). The time for complete decomposition of leaf litter varies enormously in different regions. It is generally rapid in tropics, e.g.,

Received 12 September 2004. Revision received 5 May 2005. Accepted 4 August 2005. Published on the NRC Research Press Web site at http://cjm.nrc.ca on 25 November 2005.

A.M.C. Tang, ${ }^{1}$ R. Jeewon, and K.D. Hyde. Centre for Research in Fungal Diversity, Department of Ecology and Biodiversity, University of Hong Kong, Hong Kong SAR, Republic of China.

'Corresponding author (e-mail: alvtangme@yahoo.com.hk).
2 months for Magnolia liliifera (Promputtha et al. 2002), 12 months for leaves of Phoenix hanceana (Yanna and Hyde 2002), 14 months for leaves of Saccharum officinarum (Hudson 1962), and 2 years for litter of Ananas comosus (Tiwari et al. 1994), while in temperate regions, $50 \%$ of the original litter mass remained following a 3 year study of leaf decomposition of Fagus crenata (Osono and Takeda 2001), and 95\% degradation of Pteridium aquilinum was estimated to take 11-23 years (Frankland 1976, 1998).

Definitions of the term fungal succession have been reviewed and modified recently (Neville and Webster 1995; Frankland 1998; Fryar 2002; Suzuki et al. 2002). Fryar (2002) suggested that fungal succession may refer to the replacement of fungal mycelium and the sequence of fungal sporulation. Suzuki et al. (2002) pointed out that the term may be used to describe the replacement of fungi over time at different scales, at the level of both ecosystem (macroscale) and substrata (microscale). Fungal successions on leaf litter have been well documented in temperate regions over many decades (Hudson 1962; Kendrick and Burges 1962; Meredith 1962; Hogg and Hudson 1966; Wildman and Parkinson 1979; Kuter 1986; Gamundi et al. 1987), but there have only been a few studies in tropical or subtropical regions (Promputtha et al. 2002; Tokumasu and Aoiki 2002; Yanna and Hyde 2002; Zhou and Hyde 2002; Paulus et al. 2005).

Castanopsis (Fagaceae) is an evergreen tree genus comprising about 120 species, found mostly in Asia. Castanopsis fissa (Champion ex Bentham) Rehder \& E.H. Wilson is a fast-growing native evergreen tree present as an impor- 
tant component of woodlands that presently exist in South China. Their relatively shade-tolerant seedlings and saplings (Cornelissen 1993) make it a very successful pioneer plant (Kamijo et al. 2002; Miura and Yamamoto 2003) and a candidate for plantation in Hong Kong and elsewhere (Corlett and $\mathrm{Ng} 2003$ ). Based on the archaeological excavation of many fruits of Castanopsis, Lithocarpus, and Quercus on the northeast coast of Lantau Island (Hong Kong), Zhuang and Corlett (1997) also inferred the probable prominent role of Fagaceae in the original forest cover of the region. Diverse fungal species, including anamorphic and teleomorphic ascomycetes and basidiomycetes, have been reported from different species of Castanopsis in China, Korea, India, Indonesia, Japan, Nepal, Papua New Guinea, Taiwan, and the United States (e.g., Anonymous 1979); Tai 1979; Shaw 1973. 1984: Hsieh et al. 1997; Zhuang and Wang 1997; Chen 2002). However, none of the studies have evaluated the fungal succession on Castanopsis leaves and there are virtually no records of fungi on Castanopsis fissa.

The main purpose of this study was to assess the natural fungal colonization on leaves of Castanopsis fissa and to investigate the similarities between frequency and time of occurrence of fungal taxa on those leaves. Leaves were also autoclaved to reveal the effect of autoclaving on fungal colonization

\section{Materials and methods}

\section{Study site}

Hong Kong is situated on the southern coast of China and has a subtropical monsoon climate with hot wet summers and cool dry winters (Dudgeon and Corlett 1994). The mean monthly temperature ranges from $15.8^{\circ} \mathrm{C}$ in January to $28.8^{\circ} \mathrm{C}$ in July. Mount Nicholson $\left(22^{\circ} 16^{\prime} \mathrm{N}, 114^{\circ} 11^{\prime} \mathrm{E}\right)$ is located on the midway along the northern side of Hong Kong Island. It is a lowland forest of about 70-100 years old and ranges from 300 to $430 \mathrm{~m}$. The major canopy species of the site include Endospermam chinensis (Euphorbiaceae), Crclobalanopsis neglecta (Fagaceae), Cryptocarya concinna (Lauraceae), and Engelhardtia roxburgiana (Juglandaceae) ( $\mathrm{Ng} 2003)$.

\section{Research design}

The succession patterns of microfungal communities occurring on fallen senescent leaves of Castanopsis fissa were monitored from November 2003 to March 2004. One hundred and forty yellow-brown freshly fallen leaves were collected from Mount Nicholson on 28 October 2003 (dry season). In the major part of the study, untreated leaves were used to assess the patterns of natural fungal colonization. Ten leaves were randomly selected to represent Day 0. Other leaves were placed in nylon mesh bags $(20 \mathrm{~cm} \times 35 \mathrm{~cm}$. with $2 \mathrm{~mm}$ pores) with each bag containing 10 leaves. Bags were placed under Castanopsis fissa trees and were recovered on Days 8, 24, 40, 56, 88, and 120 .

Leaves were also autoclaved to reveal the effect of autoclaving on fungal colonization. Autoclaving was used as a treatment to kill all of the endophytes and phylloplane fungi present on the leaves. This treatment was adopted to assess the fungal colonization patterns on completely sterilized leaves. After autoclaving, 10 sterilized leaves were randomly removed and incubated in sterilized plastic bags to deter- mine whether all fungi had been successfully killed. Other leaves were placed in nylon mesh bags $(20 \mathrm{~cm} \times 35 \mathrm{~cm}$, with $2 \mathrm{~mm}$ pores) with cach bag containing 10 leaves. Bags were placed under Castanopsis fissa trees and recovered on Days $8,24,40,56,88$, and 120. All of the recovered samples were returned to the laboratory and incubated at room temperature in plastic bags with moist tissue paper to promote sporulation of fungi present.

Samples were examined to identify the presence of fungal structures under a stereomicroscope. Squash mounts of fungal fruit bodies were mounted with water for measurement under differential interference contrast microscope and photographed with an Olympus DPll digital camera. Fungi were isolated by single spore isolation method (Choi et al. 1999) and maintained in the University of Hong Kong Culture Collection.

\section{Statistical analyses}

The number of leaves on which a particular fungal species was found was recorded as the number of occurrences of that fungus. Frequencies of occurrence of each fungus were calculated by the number of occurrences of that fungus divided by number of leaves examined.

Fungal taxa with an overall percent occurrence equal to or higher than 10 are regarded as dominant species. The species diversity of each treatment was calculated using the Shannon-Wiener index $(H)$ (Begon et al. 1993). The MannWhitney test was used to determine if there was any significant differences in the number of fungi between untreated leaves and autoclaved leaves.

The relative similarities of microfungal assemblages from untreated leaves at different stages of decomposition were identified by cluster analysis. A cluster dendrogram was produced from PC-ORD version 4 (McCune and Mefford 1999). Calculations were based on Sorensen distance and group average as the cluster distance measure and linkage method, respectively.

\section{Results}

Species abundance and diversity of fungi on leaf litter

A total of 140 leaves of Castanopsis fissa were examined for microfungi and 263 identifications in 38 taxa were identified (Tables 1 and 2). These comprised $29(76.3 \%)$ species of anamorphic ascomycetes. $8(20.5 \%$ ) species of teleomorphic ascomycetes, and $1(2.6 \%)$ species of zygomycetes. Most of the genera $(86.7 \%)$ collected in this survey were represented by a single species and $34.2 \%$ of the taxa recorded were collected only once. The overall dominant anamorphic ascomycete taxa were Penicillium sp. (30.7\%). Aspergillus niger $(17.9 \%)$, and Dictrochaeta parta $(12.1 \%)$, while dominant teleomorphic asconycete taxa were Arachniotus aureus $(30.7 \%)$. Mrcosphaerella sp. (14.3\%), Gnomonia petiolorum $(12.9 \%)$, and Guignardia sp. 2 (11.4\%). Of the 29 fungal genera recorded on Castanopsis fissa in this study. $76 \%$ have not previously been recorded on any Castanopsis species (Farr et al. 2004)

Shannon diversity indices showed that the species diversity of untreated leaves was highest at Day $40(H=2.34)$ and lowest at Day $8(H=1.59)$ (Table 2$)$. The average diversity of fungi on untreated leaves in the experimental period 
Tang et al.

969

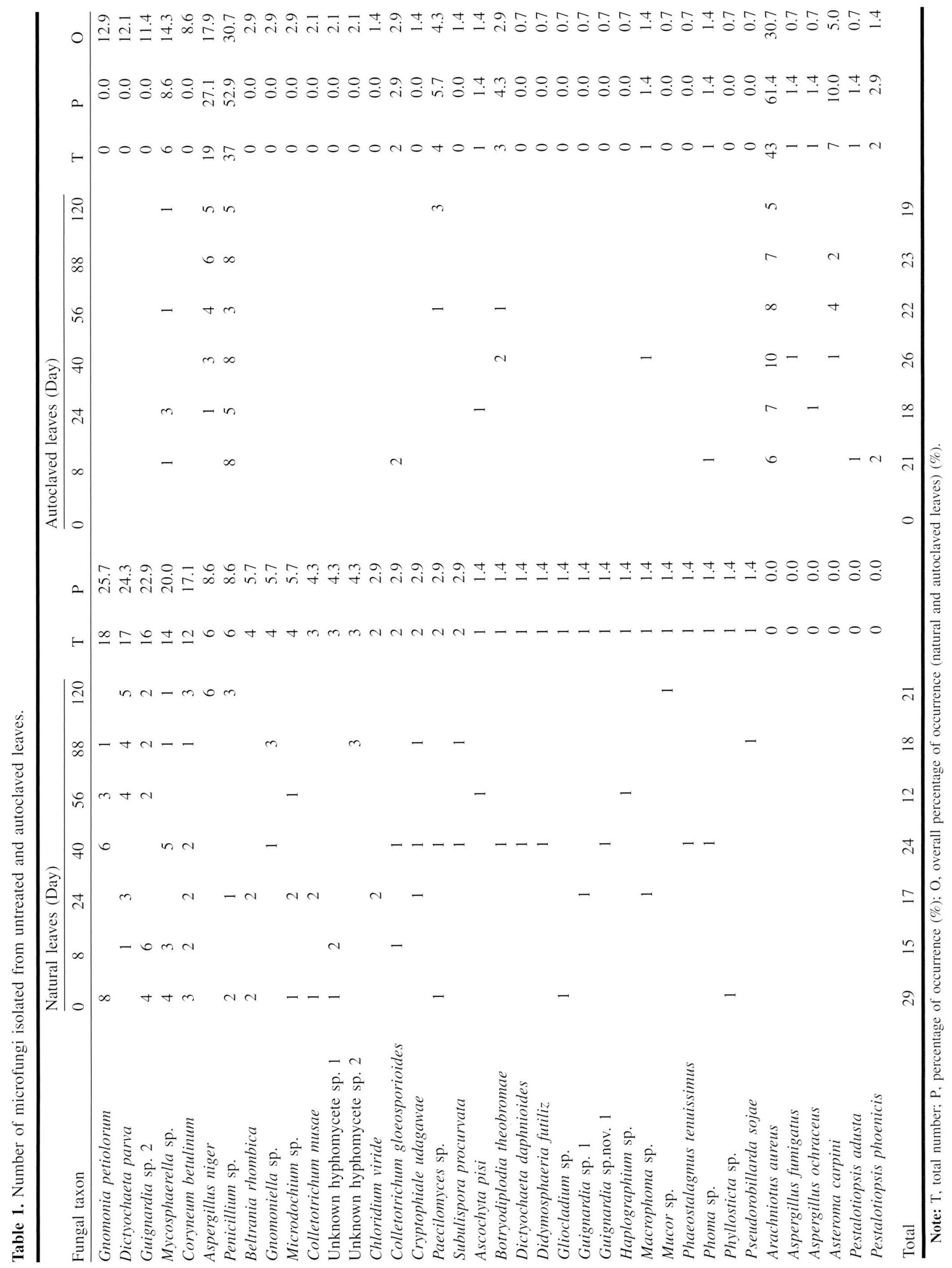

(1) 2005 NRC Canada

Reproduced with permission of the copyright owner. Further reproduction prohibited without permission. 
Table 2. Number of fungal species, total occurrence, and Shannon's diversity indices $(H)$ for untreated and autoclaved leaves.

\begin{tabular}{|c|c|c|c|c|c|c|c|c|}
\hline & \multicolumn{7}{|c|}{ Sampling time (Day) } & \multirow[b]{2}{*}{ Total } \\
\hline & 0 & 8 & 24 & 40 & 56 & 88 & 120 & \\
\hline \multicolumn{9}{|l|}{ Untreated leaves } \\
\hline No. of fungal species & 29 & 15 & 17 & 24 & 12 & 18 & 21 & 134 \\
\hline$\%$ Occurrence & 41.4 & 21.4 & 24.3 & 34.3 & 17.1 & 25.7 & 30.0 & \\
\hline$H$ & 2.20 & 1.59 & 2.23 & 2.34 & 1.63 & 2.13 & 1.78 & Mean $=1.98$ \\
\hline \multicolumn{9}{|l|}{ Autoclaved leaves } \\
\hline No. of fungal species & 0 & 21 & 18 & 26 & 22 & 23 & 19 & 129 \\
\hline$\%$ Occurrence & 0 & 30.0 & 25.7 & 37.1 & 31.4 & 32.9 & 27.1 & \\
\hline$H$ & 0 & 1.49 & 1.63 & 1.55 & 1.68 & 1.29 & 1.50 & Mean $=1.31$ \\
\hline
\end{tabular}

was 1.98. The species diversity of autoclaved leaves was the highest at Day $56(H=1.68)$ and lowest at Day $88(H=$ 1.29). The average diversity of fungi on untreated leaves in the study period was 1.31 .

\section{Similarities among fungi during fungal succession}

The analysis of the similarities of microfungi on untreated leaves generated a cluster dendrogram with four groups (Fig. 1). Group I comprised four species: Gnomonia petiolorum, Guignardia sp. 2, Mycosphaerella sp., and Coryneum betulinum. They were isolated more or less throughout the study period and identified as regular inhabitants. Group II comprised four species: Dictyochaeta parva, Aspergillus niger, Penicillium sp., and Mucor sp. They were late colonizers that occurred from Day 88 to Day 120 . Group III comprised 11 species: Beltrania rhombica, Colletotrichum musae, Microdochium sp., Chloridium viride, Macrophoma sp., Guignardia sp.1, unknown hyphomycete sp. 1, Dictyochaeta parva, Paecilomices sp., Gliocladium sp., and Phyllosticta sp. They were early colonizers, occurring from Day () to Day 24, with the occurrence significantly reduced at the later stages of decomposition. Group IV comprised 14 species: Ascochyta pisi, Botryodiplodia theobromae, Colletotrichum gloeosporioides, Cryptophiale adagawae. Dictyochaeta daphnioides, Didrmosphaeria futiliz, Gnomoniella sp., Guignardia sp.nov. 1, Haplographium sp., Phaeostalagmus tenuissimus, Phoma sp., Pseudorobillarda sojae, Subulispora procurvata, and unknown hyphomycete sp. 2. They were the midstage colonizers that occurred from Day 40 to Day 56.

\section{Effect of autoclaving on fungal succession}

There was a significant difference (Mann-Whitney test, $P=$ $0.001)$ between the fungal assemblages on untreated and autoclaved leaves. A total of 129 isolates in 15 taxa were identified from autoclaved leaves and 134 isolates in 33 taxa were isolated from untreated leaves. Autoclaved leaves were dominated by Arachniofus alureus $(61.4 \%)$, Penicilliam sp. $(52.9 \%)$, and Aspergillus niger $(27.1 \%)$, while untreated leaves were dominated by Gnomonia petiolorum (25.7\%), Dictyochaeta parva (24.3\%), Guignardia sp. 2 (22.9\%), Mycosphaerella sp. (20\%), and Coryneum betulinum (17.1\%). Two treatments resulted in $27 \%$ of overlapping fungal taxa. With the exception of Mycosphaerella sp., all of the dominant taxa on untreated leaves were not isolated from autoclaved leaves. Patterns of fungal colonization on autoclaved were quite homogeneous, with only a few species dominating throughout the decomposition period.

\section{Discussion}

Species abundance and diversity of fungi on leaf litter

This is the first account of the microfungal successional patterns on decaying leaves of Castanopsis and the first study of fungal assemblages on leaves of Castanopsis fissa. The high percentage $(76 \%)$ of the fungal taxa (genus leve) not previously recorded indicates that further studies are necessary to understand the role of these decomposer organisms on leaf decay of Castanopsis and their interactions on it.

This study recovered some genera common to other succession studies (Frankland 1998: Promputtha et al. 2002; Tokumasu and Aoiki 2002; Yanna and Hyde 2002; Zhou and Hyde 2002; Paulus et al. 2005). The soil fungal taxon Dictyochaeta has been reported in many previous studies as a highly abundant genus (Tokumasu and Aoiki 2002; Yanna and Hyde 2002; Zhou and Hyde 2002; Paulus et al. 2005), while Aspergillus and Penicillium are ubiquitous fungi. The presence of Mycosphaerella and Gnomonia as dominant fungi throughout the succession in the current study, however, was not previously recorded in the tropics. These have only been recorded in temperate regions where fungal succession studies were assessed in species of Quercus (Fagaceae), Betula (Betulaceae), Corylus (Betulaceae), and Fraxinus (Oleaceac) (Frankland 1998).

\section{Similarities among fungi during fungal succession}

The replacement of microfungi in stages of succession on decaying leaves has been categorized according to the temporal replacement of fungi: pioneer (carly) community, mature (middle-stage) community, and impoverished (later) community (Dix and Webster 1985; Gessner et al. 1993; Yanna and Hyde 2002). This replacement is likely to be attributed to the degradation of substrates over time and subsequent availability of the remaining nutrients to the decomposers that utilize those nutrients (Osono et al. 2003).

Our result from the analysis of similarities of microfungi by cluster analysis supports the suggested threc successional stages of decomposition and a group of regular inhabitants (Dix and Webster 1985; Gessner et al. 1993; Yanna and Hyde 2002; Zhou and Hyde 2002). The carly community (Group III) comprised pioneer saprotrophs (Fig. 1). They are characterized by fast-growing and short-lived taxa with a 

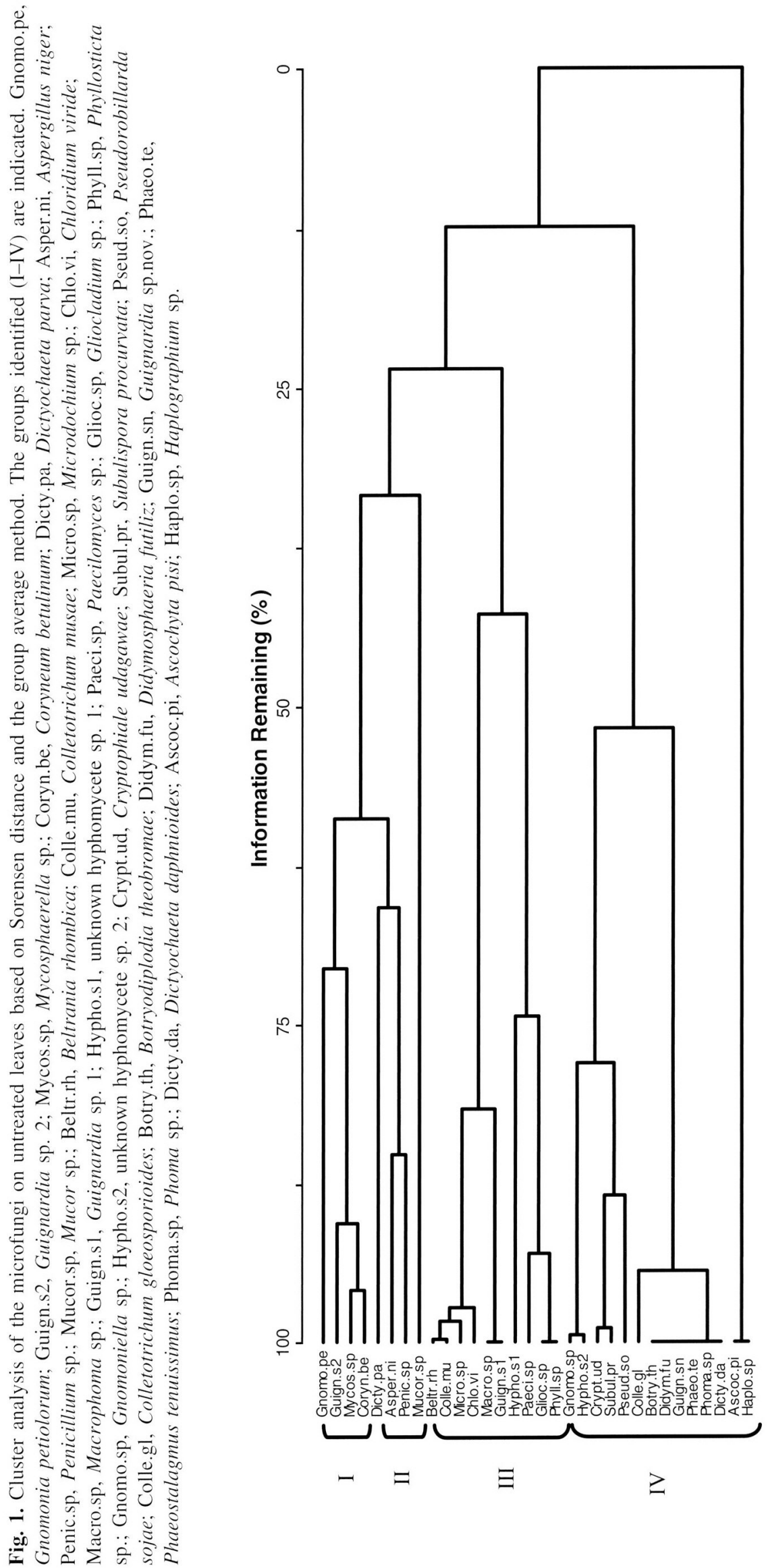
low percentage of abundance (Gessner et al. 1993; Neville and Webster 1995). Osono and Takeda (2001) suggested that this fungal group may depend on nonlignified holocellulose or soluble carbohydrates for their growth. The middle-stage community (Group IV) comprised a large group of species with a low percentage of abundance (Fig. 1; Table 1). This high diversity $(H=2.34)$ is likely to correspond to the highest rates of decomposition (Yanna and Hyde 2002). The impoverished community (Group II) was dominated by a few species with a high level of abundance. Aspergillus, Dictyochaeta, and Penicillium were the dominant species of this community. They have been shown to be efficient producers of enzymes for cellulose degradation (Decker et al. 2000: Lynd et al. 2002).

Another ecologically interesting finding was the dominance of the regular inhabitants (Group I) Gnomonia, Guignardia, and Mycosphaerella on leaves throughout the decomposition processes. These fungal genera have long been documented as hemibiotrophs or pathogens owing to their common occurrence in woodland plants (e.g. Betula, Corylus, Fraximus, and Quercus) and economically important plants (e.g.. Eucalyptus, Linum, Vitis, and Triticum) (Luttrell 1974; Swart 1975; Parbery 1996; Crous 1998; Frankland 1998). Their occurrence with extremely intensive fruiting structures over the whole leaves on Day 0 may indicate their hemibiotrophic origin. Their ecology and wide occurrence on senescent leaves deserve further study.

\section{Effect of autoclaving on fungal succession}

Autoclaving significantly affects the fungal assemblages on leaves. The completely sterilized, autoclaved leaves were mainly decomposed by a similar group of fungi (Arachniotus. Aspergillus, Mycosphaerella, and Penicllium) that were present more or less throughout the decomposition period. No clear patterns of replacement of fungal communities were observed. This group is only comparable with the late colonizers on untreated leaves. The low overlap between autoclaved and untreated leaves may suggest that two kinds of leaves were decomposed by saprobes originated from different fungal pools, such as the presence of hemibiotrophs for untreated leaves. However, more studies need to be done to find out the reasons for this and there may be an alternalive explanation for the difference in fungal assemblages, since autoclaving may alter the chemical composition of leaves, thus influencing the types of fungi that utilize the substrate.

\section{Factors regulating leaf decomposition}

Differences in factors regulating the decomposition rate result in time variations for complete degradation among species. Physicochemical factors seem to be the obvious determinants for decomposition. Dry and low winter temperature (mean $15.8-22.2{ }^{\circ} \mathrm{C}$ with 7 days at $10^{\circ} \mathrm{C}$ or below) in Hong Kong during the study period may have a direct influence on leaf senescence and decomposer activities and thus result in a longer time for decomposition than Magnolia liliifera in Thailand (2 months) (Promputtha et al. 2002) and Ficus pleurocarpa in Australia (3 months) (Paulus et al. 2005). However, physical (toughness, mass, and particle size) and chemical (nutrient content and nature and quantity of secondary compound) composition should become more important in considering the rate and hence the time for complete degradation (Melillo et al. 1982; Couteaux et al. 1995; Choong 1996). Although toughness may seem more related to herbivory than to fungi, it is directly related to the complexity of the structure and differences in the cell wall components (e.g., cellulose and lignin) to be utilized by eligible fungi. Toughness is higher in lignified cell walls $\left(4.2 \mathrm{~kJ} \cdot \mathrm{m}^{-2}\right)$ than in nonlignified cell walls $\left(3.4 \mathrm{~kJ} \cdot \mathrm{m}^{-2}\right)$ (Lucas et al. 1995), while midrib veins $\left(2-9 \mathrm{~kJ} \cdot \mathrm{m}^{-2}\right)$ and secondary veins $\left(2-4 \mathrm{~kJ} \cdot \mathrm{m}^{-2}\right)$ were estimated as the toughest structures compared with only $0.407 \mathrm{~kJ} \cdot \mathrm{m}^{-2}$ at the lamina within Castanopsis fissa leaves (Choong 1996). It was suggested that the decomposition rate of the later stages is much slower than that of the preceding ones owing to the accumulation of more recalcitrant constituents in the residual litter mass (Sundarapandian and Swamy 1999). Thus, leaves, as our experimental species, with tougher veins and lamina should result in a longer time for complete degradation. Despite the physical composition, Castanopsis fissa leaves also contain $3.5 \%$ of the phenolic concentration in dry mass found in palisade and spongy mesophyll where leaf parts cannot be toughened and other triterpenes in the epidermis and cuticle (Choong 1996). Secondary compounds have been proven to cause a more negative effect on decomposition rates than nitrogen and lignin (Palm and Sanchez 1990). However, there are only a few studies available on the effect of leaf physical and chemical composition on decomposition rate (Vallis and Jones 1973; Palm and Sanchez 1990). Further studies should focus on these aspects.

\section{Acknowledgements}

A.M.C. Tang is grateful to the University of Hong Kong for the award of a postgraduate studentship. V. Dhanasekaran and E.H.C. McKenzie are acknowledged for help in identifying fungi.

\section{References}

Abdel-Raheem, A., and Shearer, C.A. 2002. Extracellular enzyme production by freshwater ascomycetes. Fungal Diversity, 11: 1-19.

Anonymous. 1979. List of plant diseases in Taiwan. Plant Protection Society. Taiwan. Republic of China.

Begon, M., Harper, J.L., and Townsend. C.R. 1993. Ecology: individuals, population and communities. 3rd ed. Blackwell, Boston. Massachusetts.

Chen, M.M. 2002. Forest fungi phytogeography: forest fungi phytogeography of China. North America, and Siberia and international quarantine of tree pathogens. Pacific Mushroom Research and Education Center, Sacramento, California.

Choi, Y.W., Hyde, K.D., and Ho, W.H. 1999. Single spore isolation of fungi. Fungal Diversity, 3: 29-38.

Choong, M.F. 1996. What makes a leaf tough and how this affects the pattern of Castanopsis fissa leaf consumption by caterpillars. Funct. Ecol. 10: 668-674.

Corlett, R.T. and Ng, S.C. 2003. (University of Hong Kong.) Personal communication.

Comelissen. J.H.C. 1993. Ahoveground morphology of shade-tolerant Castanopsis fargesii saplings in response to light environment. Int. J. Plant Sci. 154: 481-495. 
Cotrufo, M.F., Miller, M., and Zeller, B. 2000. Litter decomposition. In Carbon and nitrogen cycling. Edited by E.D. Schulze. Springer-Verlag, Heidelberg, Germany.

Couteaux, M.M., Bottner, P., and Berg, B. 1995. Litter decomposition, climate and litter quality. Trends Ecol. Evol. 10: 63-66.

Crous, P.W. 1998. Mycosphaerella spp., and their anamorphs associated with leaf spot diseases of Eucalyptus. APS Press, St. Paul, Minnesota.

Decker, C.H., Visser, J., and Schreier, P. 2000. B-Glucosidases from five black Aspergillus species: study of their physico-chemical and biocatalytic properties. J. Agric. Food Chem. 48: 4929-4936.

Dix, N.J., and Webster, J. 1985. Fungal ecology. Chapman and Hall, London, UK.

Dudgeon, D., and Corlett, R.T. 1994. Hills and streams: an ecology of Hong Kong. Hong Kong University Press, Hong Kong.

Farr, D.F., Rossman, A.Y., Palm, M.E., and McCray, E.B. 2004. Fungal databases, systematic botany and mycology laboratory Ionline]. US Department of Agriculture. Agricultural Research Service. [Available from http://nt.ars-grin.gov/fungaldatabases/; cited 6 May 2004].

Frankland, J.C. 1976. Decomposition of bracken litter. Bot. J. Linn. Soc. 73: $133-143$.

Frankland, J.C. 1998. Presidential address: fungal succession unraveling the unpredictable. Mycol. Res. 102: $1-15$.

Fryar, S.C. 2002. Fungal succession or sequence of fruit bodies? Fungal Diversity, 10: 5-10.

Gamundi, I.J., Arambarri, A.M., and Spinedi, H.A. 1987. Fungal succession in Nothofagus deombeyi leaf litter. Rev. Mus. La Plata Secc. Bot. 14: 89-116.

Gessner, M.O.. Thomas, M., Jean-Louis, A.M., and Chauvet, E. 1993. Stable successional patterns of aquatic hyphomycetes on leaves decaying in a summer cool stream. Mycol. Res. 97: 163172.

Hogg, B.M., and Hudson, H.J. 1966. Micro-fungi on leaves of Fagus sylvatica. I. Trans. Br. Mycol. Soc. 49: 185-192.

Hsieh, W.H., Chen, C.Y., and Sivanesan, A. 1997. Some new ascomycetes from Taiwan. Mycol. Res. 101: 897-907.

Hudson, H.J. 1962. Succession of micro-fungi on ageing leaves of Saccharum officinarum. Trans. Br. Mycol. Soc. 45: 395-423.

Kamijo, T., Kitayama, K., Sugawara, A., Urushimichi, S., and Sasai, K. 2002. Primary succession of the warm-temperate broad-leaved forest on a volcanic island, Miyake-Jima, Japan. Folia Geobot. 37: 71-79.

Kendrick, B., and Burges, A. 1962. Biological aspects of Pinus sylvestris leaf litter. Nova Hedwigia, 4: 313-342.

Kjøller, A., and Struwe, S. 1982. Microfungi in ecosystems: fungal occurrence and activity in litter and soil. Oikos, 39: 389-422.

Kuter, G.A. 1986. Microfungal populations associated with the decomposition of sugar maple leaf litter. Mycologia, 78: 114-126.

Lucas, P.W., Darvell, B.W., Lee, P.K.D., and Yuen, T.D.B. 1995. The toughness of plant cell walls. Philos. Trans. R. Soc. Lond. B Biol. Sci. 348: 363-372.

Luttrell, E.S. 1974. Parasitism of fungi on vascular plants. Mycologia, 66: $1-15$.

Lynd, L.R., Weimer, P.J., van Zyl, W.H., and Pretorius, I.S. 2002. Microbial cellulose utilization: fundamentals and biotechnology. Microbiol. Mol. Biol. Rev. 66: 506-577.

Marumoto, T., Anderson, J.P.E., and Domsch, K.H. 1982. Mineralization of nutrients from soil microbial biomass. Soil Biol. Biochem. 24: 805-813.

McCune, B., and Mefford, M.J. 1999. PC-ORD: multivariate analysis of ecological data. Version 4 [computer program]. MjM software Design, Gleneden Beach, Oregon.
Melillo, J.M., Aber, J.C., and Muratore, J.F. 1982. Nitrogen and lignin control of hardwood leaf litter decomposition dynamics. Ecology, 63: 621-626.

Meredith, D.S. 1962. Some fungi on decaying banana leaves in Jamaica. Trans. Br. Mycol. Soc. 45: 335-347.

Miura, M., and Yamamoto, S. 2003. Structure and dynamics of a Castanopsis cuspidata var. sieboldii population in an old-growth, evergreen, broad-leaved forest: the importance of sprout regeneration. Ecol. Res. 18: 115-129.

Neville, D.D., and Webster, J. 1995. Fungal ecology. 2nd ed. Chapman and Hall, London, UK.

Ng, S.C. 2003. (Kadoorie Farm and Botanic Garden, Hong Kong.) Personal communication.

Osono, T., and Takeda, H. 2001. Organic chemical and nutrient dynamics in decomposing beech leaf litter in relation to fungal ingrowth and succession during 3-year decomposition processes in a cool temperate deciduous forest in Japan. Ecol. Res. 16: 649-670.

Osono, T., Fukasawa, Y., and Takeda, H. 2003. Roles of diverse fungi in larch needle-litter decomposition. Mycologia, 95: 820826.

Palm, C.A., and Sancher, P.A. 1990. Decomposition and nutrient release patterns of the leaves of three tropical tree legumes. Biotropica, 22: 330-338.

Parbery, D.G. 1996. Trophism and ecology of fungi associated with plants. Biol. Rev. Camb. Philos. Soc. 71: 473-527.

Paulus, B., Gadek, P., and Hyde, K.D. 2005. Successional patterns of microfungi in fallen leaves of Ficus pleurocarpa (Moraceae) in an Australian tropical rainforest. Biotropica. In press.

Promputtha, I., Lumyong, S., Lumyong, P., McKenzie, E.H.C., and Hyde, K.D. 2002. Fungal succession on senescent leaves of Manglietia garrettii in Doi Suthep-Pui National Park, northern Thailand. Fungal Diversity, 10: 89-100.

Risna. R.A.. and Suhirman. 2002. Ligninolytic enzyme production by Polyporaceae from Lombok, Indonesia. Fungal Diversity, 9: $123-134$

Shaw. C.G. 1973. Host fungus index for the Pacific Northwest I. Hosts. Wash. State Univ. Agric. Exp. Stn. Bull. No. 765.

Shaw, D.E. 1984. Microorganisms in Papua New Guinea. Dep. Primary Ind. Res. Bull. No. 33.

Sundarapandian, S.M., and Swamy, P.S. 1999. Litter production and leaf-litter decomposition of selected tree species in tropical forests at Kodayar in the Western Ghats, India. For. Ecol. Manag. 123: $231-244$.

Suzuki, A., Uchida, M., and Kita, Y. 2002. Experimental analyses of successive occurrence of ammonia fungi in the field. Fungal Diversity, 10: 141-165.

Swart, H.J. 1975. Australian leaf-inhabiting fungi. VIII. An interesting ascomycetes with an associated mycoparasite. Trans. Br. Mycol. Soc. 65: 83-89.

Swift, M.J., Heal, O.W., and Anderson, J.M. 1979. Decomposition in terrestrial ecosystems. Blackwell, Oxford, UK.

Tai, F.L. 1979. Sylloge Fungorum Sinicorum. Science Press, Beijing, Republic of China.

Tiwari, S.C., Tiwari, B.K.. and Mishra, R.R. 1994. Succession of microfungi associated with the decomposing litter of pineapple (Ananas comosus). Pedobiologia, 38: 185-192.

Tokumasu, S., and Aoiki, T. 2002. A new approach to studying microfungal succession on decaying pine needles in an oceanic subtropical region in Japan. Fungal Diversity, 10: 167-183.

Urairuj, C., Khanongnuch, C., and Lumyong, S. 2003. Ligninolytic enzymes from tropical endophytic Xylariaceae. Fungal Diversity, 13: 209-219. 
Vallis, I., and Jones, R.J. 1973. Net mineralization of nitrogen in leaves and leaf litter of Desmodium introtum and Phaseolus atropurpureus mixed with soil. Soil Biol. Biochem. 5: 391-398.

Wildman. H.G., and Parkinson, D. 1979. Microfungal succession on living leaves of Populus tremuloides. Can. J. Bot. 57: 2800-2811.

Williams. S.T., and Gray, T.R.G. 1974. Decomposition of litter on the soil surface. In Biology of plant litter decomposition. Edited by C.H. Dickinson and G.L.F. Pugh. Academic Press, London, UK.

Yang. J.C.. and Insam, H. 1991. Microbial biomass and relative contributions of bacteria and fungi in soil beneath tropical rain forest. Hainan Island, China. J. Trop. Ecol. 7: 385-395.
Yanna, Ho, W.H., and Hyde, K.D. 2002. Fungal succession on fronds of Phoenix hanceana in Hong Kong. Fungal Diversity. 10: $185-211$.

Zhou, D.Q., and Hyde, K.D. 2002. Fungal succession on bamboo in Hong Kong. Fungal Diversity, 10: 213-227.

Zhuang, W.Y., and Wang. Z. 1997. Notes on sclerotiniaceous fungi on Castemea and Castanopsis in Asia. Mycotaxon, 64: 449-454. Zhuang, X., and Corlett, R.T. 1997. Forest and forest succession in Hong Kong, China. J. Trop. Ecol. 14: 857-866 